\title{
Protective effects of flavonoids against rubratoxin $B$ toxicity in human hepatocellular carcinoma cells
}

\author{
Krishan Datt SHARMA ${ }^{1}$ and Hitoshi NAGASHIMA* \\ National Food Research Institute \\ (2-1-12 Kannondai, Tsukuba, Ibaraki 305-8642, Japan) \\ ${ }^{1}$ Present address: Department of Postharvest Technology, University of Horticulture \& Forestry \\ (Solan, Himachal Pradesh 173 230, India)
}

\begin{abstract}
Summary
Despite the numerous known beneficial effects of flavonoids, knowledge regarding their actions on hepatotoxicity is scanty. We therefore investigated whether the flavonoids quercetin and apigenin could protect human hepatoma cell line $\mathrm{HuH}-7$ against rubratoxin B-induced toxicity. These flavonoids alone markedly retarded cell proliferation in a dose-dependent manner. Quercetin significantly lessened the inhibitory effects of rubratoxin B on cell proliferation at all concentrations tested $(30-100 \mu \mathrm{M})$, however apigenin was protective only at low concentration $(9 \mu \mathrm{M})$. Rubratoxin B stimulated the secretion of tumor necrosis factor- $\alpha$ and macrophage colony stimulating factor, and quercetin and apigenin dose-dependently inhibited the rubratoxin B-induced secretion of these cytokines. Apigenin appears to be a more potent inhibitor of cytokine secretion than is quercetin. Together our results suggest that quercetin and apigenin are protective against rubratoxin B-induced cytotoxicity.
\end{abstract}

Key words : Quercetin, Apigenin, HuH-7 cells, cytokine

(Received: February 17, 2005, Revised \& Accepted: April 22, 2005)

\section{Introduction}

Much research effort has focused on the identification of bioflavonoids that exert beneficial effects in humans, whose average daily intake of these compounds has been estimated to range from $25 \mathrm{mg}$ to $1 \mathrm{~g}^{1,2)}$. The flavonoids quercetin and apigenin are widely distributed throughout the plant kingdom, with fruits and vegetables being the richest sources. These compounds are potential anticancer agents because they inhibit the growth of various cancer cell lines, including gastric cancer cells $^{3)}$, melanoma cells $s^{4,5}$ and hepatocellular carcinoma cells ${ }^{6}$.

Rubratoxin B is known to be a potent hepatotoxic ${ }^{7,8)}$ mycotoxin produced by certain Penicillium fungi ${ }^{8,9)}$. Rubratoxin $\mathrm{B}$ has been reported to retard cell proliferation ${ }^{10,11}$ and induce cytokine secretion in HepG $2^{12)}, \mathrm{HuH}-7^{12)}$ and HL60 ${ }^{13)}$ cells. Because rubratoxin B is thought to be an excellent model compound for exogenous stimulus ${ }^{12)}$ we used it in the present study to induce pathological changes

\footnotetext{
* Corresponding author
} 
necessary to assess the protective effects of flavonoids on this process. Specifically we sought to determine whether quercetin and apigenin could protect the hepatoma cell line HuH-7 against rubratoxin B-induced toxicity, as measured in cell proliferation and cytokine secretion assays.

\section{Materials and Methods}

Materials Quercetin (Fig. 1) and rubratoxin B were purchased from Sigma-Aldrich (USA). Apigenin (Fig. 1) was purchased from EXTRASYNTHÉSE (France). These chemicals were dissolved in dimethyl sulphoxide (DMSO). Fetal calf serum (FCS) was purchased from JRH Biosciences Inc. (USA). The human hepatocarcinoma cell line HuH-7 was purchased from RIKEN Cell Bank (Japan), and cultured in Dulbecco's Modified Eagle's medium containing 10 \% FCS.

Treatment of cells and assays Cell proliferation was assessed by measuring the incorporation of 5-bromo-2'-deoxyuridine (BrdU) during DNA synthesis as described previously ${ }^{11}$. Five times $10^{3}$ cells in $100 \mu 1$ media were placed into each well of a 96-well micro-titer plate for BrdU incorporation (Cell Proliferation ELISA, BrdU (colorimetric), Roche Diagnostics, Switzerland). After the cells were incubated overnight, the medium was replaced with medium containing $1 \%$ DMSO (v/v) and either quercetin or apigenin (at various concentrations) with or without $40 \mu \mathrm{g} / \mathrm{ml}$ rubratoxin B. Cell proliferation in treated cultures was examined after $24 \mathrm{hr}$ of incubation.

The methods used to measure tumor necrosis factor (TNF)- $\alpha$ and macrophage colony stimulating factor (M-CSF) were identical to those of Nagashima et al. ${ }^{7}$. Cells were plated in $0.5 \mathrm{ml}$ medium at a density of $10^{5}$ cells per well of a in 24-well tissue culture plate. After the cells were incubated overnight, the medium was replaced with medium containing $1 \%$ DMSO (v/v) and either quercetin or apigenin (at various concentrations) with or without $40 \mu \mathrm{g} / \mathrm{ml}$ rubratoxin B. Treated culture plates were incubated for $24 \mathrm{hr}$, and then the media were collected. The samples were centrifuged at $1,000 \times \mathrm{g}$ for $5 \mathrm{~min}$ to remove cell debris, and the resulting supernatants were used in the assays. The levels of TNF- $\alpha$ and M-CSF were quantified using Quantikine human TNF- $\alpha$ and MCSF Immunoassay Kits from R \& D Systems (USA), respectively.

Statistics Data are expressed as mean \pm standard deviation (SD). Treatment means underwent analysis of variance (ANOVA) to identify statistically significant $(\mathrm{p}<0.05)$ differences.<smiles>[X]c1cc(-c2oc3cc(O)cc(O)c3c(=O)c2[R])ccc1O</smiles>

Quercetin: $\mathrm{R}=\mathrm{OH}, \mathrm{X}=\mathrm{OH}$

Apigenin: $\mathrm{R}=\mathrm{H}, \mathrm{X}=\mathrm{H}$

Fig. 1. Chemical structures of flavonoids. 


\section{Results and Discussion}

The effects of quercetin and apigenin on the cell proliferation of HuH-7 cells are shown in Table 1. Compared with vehicle-treated control (DMSO alone), quercetin and apigenin hindered the cell proliferation significantly. The apigenin concentrations needed for strong inhibitory effects on cell growth were even lower than those of quercetin. The median inhibitory concentration $\left(\mathrm{IC}_{50}\right)$ for quercetin was $79 \mu \mathrm{M}$ and $26 \mu \mathrm{M}$ for apigenin. Like the present study, many other reports have described the inhibitory effects of quercetin ${ }^{3-6,14)}$ and apigenin ${ }^{4,5,15)}$ on cell proliferation.

Because we found that the $\mathrm{IC}_{50}$ for rubratoxin $\mathrm{B}$ against $\mathrm{HuH}-7$ cells was $38 \mu \mathrm{g} / \mathrm{ml}$ (data not shown), we chose a concentration of $40 \mu \mathrm{g} / \mathrm{ml}(77.2 \mu \mathrm{M})$ for our experiments. At all of the quercetin concentrations tested, the ratios of the values of concomitant treatment with rubratoxin $\mathrm{B}$ and quercetin to respective values of quercetin treatment alone $(74.7 \%$ at $30 \mu \mathrm{M}, 75.3 \%$ at $44 \mu \mathrm{M}, 57.0 \%$ at $67 \mu \mathrm{M}$ and $101.8 \%$ at $100 \mu \mathrm{M}$ quercetin) were higher than the ratio of the value of treatment with rubratoxin $\mathrm{B}$ alone to the value of vehicle-treated control (28.4\%) (Table 1), revealing that quercetin effectively protected the cells against the inhibitory action of rubratoxin B. Apigenin was effective only at low concentration; while $9 \mu \mathrm{M}$ apigenin apparently protected the cells against the inhibitory action of rubratoxin $\mathrm{B}$, we did not observe any protection at higher doses of apigenin (Table 1).

Rubratoxin $\mathrm{B}$ has been reported to induce the secretion of various hepatic injury-related cytokines in human cell lines ${ }^{12,13)}$ and mouse ${ }^{16)}$. Therefore, we studied the effects of quercetin and apigenin on cytokine secretion. Whereas TNF- $\alpha$ appeared in the culture media after HuH-7 cells were treated with rubratoxin B (Table 2), treatments with flavonoid alone failed to stimulate secretion of TNF- $\alpha$ into the media (data not shown). TNF- $\alpha$ is considered to play crucial roles under pathological conditions ${ }^{17,18}$, and the secretion of TNF- $\alpha$ from a rubratoxin B-treated hepatocyteoriginated hepatoma cell line suggests that hepatocyte-derived TNF- $\alpha$ secretion might contribute to the hepatotoxic effects of rubratoxin B. As reported previously ${ }^{12}$, we also detected M-CSF in the

Table 1. Action of flavonoids ${ }^{\mathrm{a}}$ on viability of rubratoxin B-treated HuH-7 cells ${ }^{\mathrm{b}}$.

\begin{tabular}{lccc}
\hline \multicolumn{1}{c}{ Flavonoid } & Concentration $(\mu \mathrm{M})$ & \multicolumn{2}{c}{ Rubratoxin $\mathrm{B}^{\mathrm{c}}(\%$ BrdU incorporation) } \\
\cline { 2 - 4 } & & - & + \\
\hline Control & 0 & $100 \pm 3.8^{\mathrm{d}}$ & $28.4 \pm 5.5^{\mathrm{d}}$ \\
Quercetin & 30 & $92.4 \pm 8.0$ & $69.0 \pm 9.9$ \\
& 44 & $79.4 \pm 2.9$ & $59.8 \pm 8.2$ \\
& 67 & $64.6 \pm 2.9$ & $36.8 \pm 6.8$ \\
Apigenin & 100 & $27.1 \pm 1.1$ & $27.6 \pm 2.6^{\mathrm{d}}$ \\
& 9 & $97.4 \pm 3.0^{\mathrm{d}}$ & $45.3 \pm 3.2$ \\
& 20 & $70.6 \pm 5.5$ & $20.7 \pm 3.0$ \\
& 30 & $39.0 \pm 2.2$ & $7.0 \pm 0.8$ \\
& 44 & $23.1 \pm 1.4$ & $6.2 \pm 1.1$ \\
\hline
\end{tabular}

\footnotetext{
${ }^{a} \mathrm{IC}_{50}$ values for quercetin and apigenin were $79 \mu \mathrm{M}$ and $26 \mu \mathrm{M}$, respectively.

${ }^{\text {b }}$ Results are mean \pm S.D., $\mathrm{n}=6$.

c Concentration of rubratoxin B was $40 \mu \mathrm{g} / \mathrm{ml}(77.2 \mu \mathrm{M})$.

d Statistically insignificant $(\mathrm{p}>0.05)$ with respective controls.
} 
Table 2. Effects of quercetin and apigenin on rubratoxin B-induced cytokine secretons ${ }^{\mathrm{a}}$ in HuH-7 cells ${ }^{\mathrm{b}}$.

\begin{tabular}{|c|c|c|c|c|c|c|c|}
\hline \multirow[t]{3}{*}{ Cytokine } & \multirow[t]{3}{*}{ Control $^{\mathrm{c}}$} & \multicolumn{6}{|c|}{ Rubratoxin $\mathrm{B}^{\mathrm{d}}$} \\
\hline & & \multicolumn{3}{|c|}{ Quercetin $(\mu \mathrm{M})$} & \multicolumn{3}{|c|}{ Apigenin $(\mu \mathrm{M})$} \\
\hline & & 0 & 25 & 100 & 0 & 10 & 25 \\
\hline TNF- $\alpha(\mathrm{pg} / \mathrm{ml})$ & N.D. & $\begin{array}{c}154.0 \pm 5.8 \\
(100 \%)\end{array}$ & $\begin{array}{c}118.8 \pm 10.7 \\
(77.2 \%)\end{array}$ & $\begin{array}{c}18.4 \pm 1.2 \\
(11.9 \%)\end{array}$ & $\begin{array}{c}154.0 \pm 5.8 \\
(100 \%)\end{array}$ & $\begin{array}{c}125.5 \pm 4.3 \\
(81.5 \%)\end{array}$ & $\begin{array}{c}6.3 \pm 1.9 \\
(4.1 \%)\end{array}$ \\
\hline M-CSF (pg/ml) & $49.1 \pm 3.2$ & $\begin{array}{l}263.2 \pm 10.4 \\
\quad(100 \%)\end{array}$ & $\begin{array}{c}229.7 \pm 4.4 \\
(87.3 \%)\end{array}$ & $\begin{array}{c}115.1 \pm 0.6 \\
(43.7 \%)\end{array}$ & $\begin{array}{c}263.2 \pm 10.4 \\
\quad(100 \%)\end{array}$ & $\begin{array}{c}200.8 \pm 6.0 \\
(76.3 \%)\end{array}$ & $\begin{array}{c}121.4 \pm 2.4 \\
(46.2 \%)\end{array}$ \\
\hline
\end{tabular}

N.D. represents not detected $(<1 \mathrm{pg} / \mathrm{ml})$.

a No TNF- $\alpha$ secretion was detected at any concentrations when cells treated with quercetin or apigenin independently, while for M-CSF reduced secretion over vehicle treated was noticed.

${ }^{\mathrm{b}}$ Results are mean \pm S.D. $(\mathrm{n}=4)$ and are statistically significant at $\mathrm{p}<0.05$.

c DMSO only.

${ }^{\mathrm{d}}$ Concentration of rubratoxin B was $40 \mu \mathrm{g} / \mathrm{ml}(77.2 \mu \mathrm{M})$.

media of rubratoxin B-treated HuH-7 cells (Table 2).

In our study, quercetin and apigenin obviously inhibited the secretion of TNF- $\alpha$ and M-CSF in rubratoxin B-treated HuH-7 cells, and the effects of both compounds on TNF- $\alpha$ and M-CSF were dose-dependent and statistically significant $(\mathrm{p}<0.05)$ (Table 2$)$. Apigenin appears to be a more potent inhibitor of cytokine secretion than is quercetin; quercetin at $25 \mu \mathrm{M}$ reduced rubratoxin B-induced TNF$\alpha$ secretion to a level of $77 \%$ and M-CSF secretion to $87 \%$, whereas apigenin at the same dose reduced the TNF- $\alpha$ level to $4 \%$ and the M-CSF level to $46 \%$ (Table 2). Likewise, Kawada et al ${ }^{14)}$ reported that quercetin inhibited lipopolysaccharide (LPS)-induced TNF- $\alpha$ secretion in rat Kupfer cells, and Matsuda et al. ${ }^{19)}$ found that this flavonoid inhibited antigen-induced TNF- $\alpha$ secretion in a rat leukemia cell line. In contrast, Wang and $\mathrm{Mazza}^{20)}$ showed that $250 \mu \mathrm{M}$ or lower concentrations of quercetin had no effect on LPS/interferon- $\gamma$-induced TNF- $\alpha$ secretion in a mouse monocyte/macrophage cell line. This apparent discrepancy may arise due to the differences in experimental conditions and/or species. The results of Smolinski and Pestka ${ }^{21)}$ are controversial; apigenin lacked a significant effect on LPS-induced TNF- $\alpha$ secretion in a mouse monocyte/macrophage cell line, however treatment of mice with apigenin clearly reduced LPS-induced TNF- $\alpha$ secretion. To our knowledge, no one has investigated the effects of these two flavonoids on M-CSF secretion.

In the present study, we showed that the flavonoids quercetin and apigenin have protective activities on rubratoxin B-caused cytotoxicity in cultured human hepatocarcinoma cells. However, further studies are needed to clarify the detailed mechanisms of their beneficial effects.

\section{References}

1 ) Hollman, P.C.H., Katan, M.B.: Food Chem. Toxicol., 37, 937-942 (1999)

2 ) Scalbert, A., Williamson, G.: J. Nutr., 130, S2073-2085 (2000)

3 ) Yoshida, M., Sakai, T., Hosokawa, N., Marui, N., Matsumoto, K., Fujioka, A., Nishino, H., Aoike, A.: FEBS Lett., 260, 10-13 (1990)

4 ) Iwashita, K., Kobori, M., Yamaki, K., Tsushida, T.: Biosci. Biotechnol. Biochem., 64, 1813-1820 (2000)

5 ) Caltagirone, S., Rossi, C., Poggi, A., Ranelletti, F.O., Natali, P.G., Brunetti, M., Aiello, F.B., Piantelli, M.: 
Int. J. Cancer, 87, 595-600 (2000)

6 ) Shi, M., Wang, F.-S., Wu, Z.-Z.: World J. Gastroenterol., 9, 73-78 (2003)

7 ) Burnside, J.E., Sippel, W.L., Forgacs, J., Carll, W.T., Atwood, M.B., Doll, E.R.: Am. J. Vet. Res., 18, 817-824 (1957)

8 ) Natori, S., Sakaki, S., Kurata, H., Udagawa, S., Ichinoe, M., Saito, M., Umeda, M., Ohtsubo, K.: Appl. Microbiol., 19, 613-617 (1970)

9 ) Wilson, B.J., Harbison, R.D.: J. Am. Vet. Med. Assoc., 163, 1274-1276 (1973)

10) Nagashima, H.: Mycotoxins, 42, 57-61 (1996)

11) Nagashima, H., Goto, T.: Toxicol. Lett., 118, 47-51 (2000)

12) Nagashima, H., Nakamura, K., Goto, T.: Toxicol. Lett., 145, 153-159 (2003)

13) Nagashima, H., Nakamura, K., Goto, T.: Biochem. Biophys. Res. Commun., 287, 829-832 (2001)

14) Kawada, N., Seki, S., Inoue, M., Kuroki, T.: Hepatology, 27, 1265-1274 (1998)

15) Sato, F., Matsukawa, Y., Matsumoto, K., Nishino, H., Sakai, T.: Biochem. Biophys. Res. Commun., 204, 578-584 (1994)

16) Nagashima, H., Nakamura, K., Goto, T.: Mycotoxins, 51, 7-12 (2001)

17) Luster, M.I., Simeonova, P.P., Gallucci, R., Matheson, J.: Crit. Rev. Toxicol., 29, 491-511 (1999)

18) Rothe, J., Lesslauer, W., Lotscher, H., Lang, Y., Koebel, P., Kontgen, F., Althage, A., Zinkernagel, R., Steinmetz, M., Bluethmann, H.: Nature 364, 798-802 (1993)

19) Matsuda, H., Morikawa, T., Ueda, K., Managi, H., Yoshikawa, M.: Bioorg. Med. Chem., 10, 3123-3128 (2002)

20) Wang, J., Mazza, G.: J. Agric. Food Chem., 50, 4183-4189 (2002)

21) Smolinski, A.T., Pestka, J.J.: Food Chem. Toxicol., 41, 1381-1390 (2003)

\section{ヒト肝癌細胞におけるルブラトキシン B の毒性に対するフラボノイドの保護作用}

クリシャン・ダット・シャルマ, 長嶋 等 : 独立行政法人食品総合研究所 $(305-8642$ つくば市観音台 2-1-12)

フラボノイドの多くの有益な作用が知られているにも関わらず，肝毒性物質に対する作用についてはあ まり知られていない. そこでヒト肝癌細胞 HuH-7 におけるルブラトキシン B の毒性に対してケルセチンと アピゲニンが保護するかどうかを調べた。両フラボノイドは, 単独では細胞増殖を用量依存的に阻害した. ケルセチンは，ルブラトキシン B の細胞増殖阻害作用を調べたどの濃度 $(30 \sim 100 \mu \mathrm{M})$ でも減少させた. これに対しアピゲニンは, 低濃度 $(9 \mu \mathrm{M})$ でのみルブラトキシン B の細胞増殖阻害作用からの保護作用が 観察された。 ルブラトキシン B は腫瘍壊死因子- $\alpha$ とマクロファージコロニー刺激因子の分泌を誘導し, ケ ルセチンとアピゲニンは用量依存的にこれらのルブラトキシン B 誘導性のサイトカイン分泌を阻害した. サ イトカイン分泌の阻害に関しては, アピゲニンのほうがケルセチンより効果が高かった.これらの結果か ら, ケルセチンとアピゲニンにはルブラトキシン B による細胞毒性から保護する作用があると考えられた.

キーワード：ケルセチン, アピゲニン, $\mathrm{HuH}-7$ 細胞, サイトカイン 